http://dx.doi.org/10.11646/zootaxa.3860.2.1

http://zoobank.org/urn:lsid:zoobank.org:pub:DD34DE75-74F3-42B1-9224-DC3BF9F3CCC7

\title{
An illustrated key to and diagnoses of the species of Staphylinidae (Coleoptera) associated with decaying carcasses in Argentina
}

\author{
FERNANDO H. ABALLAY ${ }^{1}$, MARIANA R. CHANI-POSSE', MARÍA ROSANA AYÓN², MARÍA BELÉN \\ MALDONADO $^{1} \&$ NÉSTOR D. CENTENO 3 \\ ${ }^{1}$ Laboratorio de Entomología, Instituto Argentino de Investigaciones de las Zonas Áridas (IADIZA, CCT CONICET Mendoza), \\ Casilla de correo 507, 5500 Mendoza, Argentina \\ ${ }^{2}$ Cuerpo de Investigaciones Fiscales (CIF), Ministerio Público de Salta, Avda. Bolivia 4671 CP 4400, Salta Capital, Argentina \\ ${ }^{3}$ Laboratorio de Entomología Aplicada y Forense, Universidad Nacional de Quilmes, Roque Sáenz peña 180, B1876BXD, Bernal, \\ Buenos Aires, Argentina \\ Corresponding author: Fernando H. Aballay (faballay@mendoza-conicet.gob.ar)
}

\begin{abstract}
A key to 24 Staphylinidae species associated with decaying carcasses in Argentina is presented, including diagnoses, illustrations, distributional and bionomical data for these species. This article provides a table of all species associated with carcasses, detailing the substrate from which they were collected and geographical distribution by province. All 24 Staphylinidae species recorded are grouped into three subfamilies: Aleocharinae (three species of Aleochara Gravenhorst and one species of Atheta Thomson), Oxytelinae (one species of Anotylus Thomson) and Staphylininae (18 species, two belonging to the tribe Xantholinini and 16 species belonging to the tribe Staphylinini). A discussion is presented on the potential forensic importance of some species collected on human and pig carcasses.
\end{abstract}

Key words: Key, Staphylinidae, Aleocharinae, Oxytelinae, Staphylininae, forensic, carcasses, Argentina

\section{Introduction}

Beetles are one of the most diverse components of carrion substrates and their forensic importance has been well documented (e.g., Smith 1986; Benecke 1988; Matuszewski et al. 2008; Midgley et al. 2010; Villet 2011). Despite the high diversity of beetles found in carcasses, most forensic studies have been focused on Diptera due to the fact that they colonize the body from the beginning of the decomposition process (Goff 1993). However, Diptera have little usefulness after several weeks or months, when the body is in advanced stages of decomposition. Beetles have been found to be the main entomological evidence present in a corpse in advanced decomposition stages and their usefulness to estimate the minimum Post Mortem Interval (PMIm) has been emphasised (Kulshrestha \& Satpathy 2001; Midgley et al. 2010; Matuszewski 2012; Prado e Castro et al. 2013). The correct identification of insects and knowledge of their life history as well as the duration of each stage of development leads to accurately establishing the PMI (Turchetto \& Vanin 2004). Families of beetles of forensic importance are Dermestidae, Cleridae, Histeridae, Staphylinidae, Nitidulidae, Scarabaeidae, Silphidae, Tenebrionidae, and Trogidae (Mise et al. 2007; Almeida \& Mise 2009; Byrd \& Castner 2009; Özdermir \& Sert 2009; Battán Horenstein \& Linhares 2011). Members of these families may play different roles in the community depending on the feeding behaviour of their adults or their immature stages. Beetles can feed on cadaveric tissues (necrophagous) or on other insects in the body, such as larvae of Diptera or other Coleoptera species (necrophilous) (Smith 1986).

The beetle family Staphylinidae, including the recently added Scydmaeninae, has become the largest in Coleoptera and in the whole of the Animal Kingdom, with over 56,000 described species (Grebennikov \& Newton 2009) currently organized in 32 subfamilies (Bouchard et al. 2011). The overall classification, phylogeny, world distribution, morphology and biology were reviewed most recently by Thayer (2005).

Staphylinidae have been frequently cited as the most diverse coleopterous group found on carcasses. These 
dipteran puparia (Klimaszewski 1984). The females lay their eggs in sites infested with fly larvae, and the newly emerged first-instar larvae hunt for dipteran pupae, feeding on them until pupation takes place, either in the soil or within host puparia (Klimaszewski \& Jansen 1993). Species of this genus have been reported of great importance to determine the PMI (Mise et al. 2007; Lin \& Shiao 2013). Creophilus maxillosus is a common fly predator associated with decomposing cadavers and carcasses and it is one of the most cited species in the forensic literature, due to its utility for the estimation of both the PMI and the PAI (e.g., Battán Horenstein et al. 2012; Matuszewski 2012; Matuszewski \& Szafalowicz 2013). Philonthus species have been also repeatedly found in association with carcasses (e.g., Matuszewski et al. 2010; Fernández et al. 2010; Aballay et al. 2008, 2012; Matuszewski \& Szafalowicz 2013), but their potential as forensic indicators has been much less assessed as well as that of species belonging to other Staphylininae genera cited in the present study.

Further research is needed to determine the specific time period in the cadaver succession for which other species studied herein could be used to estimate PMI indicators based on succession patterns. Additionally, immature stages may also be useful in forensic entomology because they are reared within the body and were collected in advanced stages of decomposition (Aballay pers. obs.). We expect that this key will contribute to further studies on the potential role of carrion-frequenting Staphylinidae as PMI indicators.

\section{Acknowledgments}

Our thanks to Cecilia Herrera and Marcela Godoy (Medical Forensic Committee of Mendoza) for providing collecting permits on human carcasses; Gustavo E. Flores for suggestions improving the manuscript; Ana María Scollo for mounting specimens; Germán San Blas and Federico Agrain for help in taking photographs; Rodolfo Carrara for GIS assistance; Jan Klimaszewski (Editor Staphylinidae) and two anonymous reviewers for suggestions for improving this paper. We are also indebted to Stylianos Chatzimanolis, Christian Maus and Afred F. Newton for their valuable help with the identification of some specimens. Financial support was provided by grants of the Agencia Nacional de Promoción Científica y Tecnológica (ANPCYT), (PICT 2013-0514), Universidad Nacional de Quilmes to FHA and Consejo Nacional de Investigaciones Científicas y Técnicas (CONICET, Argentina), Servicios Tecnológicos de Alto Nivel (STAN CONICET)(ST 826) and CONICET PIP 112-201101-00987.

\section{References}

Aballay, F.H. (2012) Estudios estacionales en composición, colonización y asociación de la entomofauna cadavérica, en relación a los estadios de descomposición en zonas áridas de llanura y de altura. Ph.D. Thesis, Universidad Nacional de Quilmes, Buenos Aires province.

Aballay, F.H., Murúa, A.F., Acosta, J.C. \& Centeno, N. (2008) Primer registro de artropodofauna cadavérica en sustratos humanos y animales en San Juan, Argentina. Revista de la Sociedad Entomológica Argentina, 67, 157-163.

Aballay, F.H., Murúa, A.F., Acosta, J.C. \& Centeno, N.D. (2012) Succession of carrion fauna in the arid region of San Juan province, Argentina: its forensic relevance. Neotropical Entomology, 41, 27-31. http://dx.doi.org/10.1007/s13744-011-0005-9

Almeida, L.M. \& Mise, K.M. (2009) Diagnosis and key of the main families and species of South American Coleoptera of forensic importance. Revista Brasileira de Entomologia, 53 (2), 227-244. http://dx.doi.org/10.1590/S0085-56262009000200006

Arnaldos, M.I., García, M.D., Romera, E., Presa, J.J. \& Luna, A. (2005) Estimation of postmortem interval in real cases based on experimentally obtained entomological evidence. Forensic Science International, 149, 57-65. http://dx.doi.org/10.1016/j.forsciint.2004.04.087

Battán-Horenstein, M. \& Linhares, A.X. (2011) Seasonal composition and temporal succession of necrophagous and predator beetles on pig carrion in central Argentina. Medical and Veterinary Entomology, 25, 395-401. http://dx.doi.org/10.1111/j.1365-2915.2011.00969.x

Battán-Horenstein, M., Rosso, B. \& García, D.M. (2012) Seasonal structure and dynamics of sarcosaprophagous fauna on pig carrion in a rural area of Cordoba (Argentina): Their importance in forensic science. Forensic Science International, 217, $146-156$. http://dx.doi.org/10.1016/j.forsciint.2011.10.043

Benecke, M. (1998) Six forensic entomology cases: description and commentary. Journal of Forensic Sciences, 43, 797-805.

Blackwelder, R.E. (1936) Morphology of the coleopterous family Staphylinidae. Smithsonian Miscellaneous Collection, 94 (13), 1-102. 
Bouchard, P., Bousquet, Y., Davies, A.E., Alonso-Zarazaga, M.A., Lawrence, J.F., Lyal, C.H.C., Newton, A.F., Reid, C.A.M., Schmitt, M., Ślipiński, A. \& Smith, A.B.T. (2011) Family-group names in Coleoptera (Insecta). ZooKeys, 88, 1-972. http://dx.doi.org/10.3897/zookeys.88.807

Byrd, J.H. \& Castner, J.L. (2009) Insects of forensic importance. In: Castner, J.H. \& Byrd, J.L., (Eds.), Forensic entomology: the utility of arthropods in legal investigations. CRC Press, Boca Raton, pp. 39-129.

Cabrera-Walsh, G. \& Chani-Posse, M. (2003) Abundance and seasonal Distribution of predatory coprophilous Argentine rove beetles (Coleoptera: Staphylinidae), and their effects on dung breeding flies. Coleopterists Bulletin, 57 (1), $43-50$. http://dx.doi.org/10.1649/0010-065X(2003)057[0043:AASDOP]2.0.CO;2

Carvalho, L.M.L., Thyssen, P.J., Lindares, A.X. \& Palhares, F.A.B. (2000) A checklist of arthropods associated with pig carrion and human corpses in southeastern Brazil. Memórias do Instituto Oswaldo Cruz, 95, 135-138. http://dx.doi.org/10.1590/S0074-02762000000100023

Centeno, N.D., Maldonado, M. \& Oliva, A. (2002) Seasonal patterns of arthropods occuring on sheltered and unsheltered pig carcasses in Buenos Aires Province (Argentina). Forensic Science International, 126, 63-70. http://dx.doi.org/10.1016/S0379-0738(02)00037-3

Chani-Posse, M.R. (2004) Eight Argentinean species of dung-inhabiting Philonthus Stephens (Coleoptera: Staphylinidae). Studies on Neotropical Fauna and Environment, 39, 217-232. http://dx.doi.org/10.1080/01650520412331271738

Chani-Posse, M. (2006) Larval morphology and chaetotaxy of Philonthus Stephens (Coleoptera: Staphylinidae) based on descriptions of eight species from Argentina. Annales Zoologici, 56 (1), 7-28.

Chani-Posse, M. (2010) Revision of the southern South American species of Philonthus Stephens (Coleoptera: Staphylinidae). Zootaxa, 2595, 1-70.

Chani-Posse, M. \& Thayer, M.K. (2008) Staphylinidae. In: Debandi, G.O., Claps, L.E. \& Roig-Juñent, S.A. (Eds.), Biodiversidad de artrópodos argentinos, Sociedad Entomológica Argentina ediciones. Mendoza, Argentina, pp. 471-494. [ISBN 978-987-21319-2-0]

Chatzimanolis, S. (2004) A revision of the Neotropical genus Nordus (Coleoptera: Staphylinidae). Entomologische Abhandlungen, 62 (1), 3-64.

Clarke, D.J. (2011) Testing the phylogenetic utility of morphological character systems, with a revision of Creophilus Leach (Coleoptera: Staphylinidae). Zoological Journal of the Linnean Society, 163 (3), 23-812. http://dx.doi.org/10.1111/j.1096-3642.2011.00725.x

da Silva, R.C. \& Dos Santos, W.E. (2012) Fauna de Coleoptera Associada a Carcacas de Coelhos Expostas em uma Area Urbana no Sul do Brasil. EntomoBrasilis, 5 (3), 185-189. http://dx.doi.org/10.12741/ebrasilis.v5.i3.245

Dekeirsschieter, J., Frederick, C., Verheggen, F.J., Drugmand, D. \& Haubruge, E. (2013) Diversity of forensic rove beetles (Coleoptera, Staphylinidae) associated with decaying Pig carcass in a forest biotope. Journal of Forensic Science, 58 (4), $1032-1040$. http://dx.doi.org/10.1111/1556-4029.12095

Elven, H., Bachmann, L., \& Gusarov, V.I. (2010) Phylogeny of the tribe Athetini (Coleoptera: Staphylinidae) inferred from mitochondrial and nuclear sequence data. Molecular Phylogenetics and Evolution, 57, 84-100. http://dx.doi.org/10.1016/j.ympev.2010.05.023

Fernández, V., Gamarra, P., Outerelo, R., Cifrián, B. \& Baz, A. (2010) Distribución de estafilíninos necrófilos (Coleoptera, Staphylinidae, Staphylininae) a lo largo de un gradiente altitudinal en la Sierra de Guadarrama, España. Boletin de la Real Sociedad Española de Historia Natural Seccion Biologica, 104, 61-86.

Frank, J.H. \& Barrera, R. (2010) Natural history of Belonuchus Nordmann spp. and allies (Coleoptera: Staphylinidae) in Heliconia L. (Zingiberales: Heliconiaceae) flower bracts. Insecta Mundi, 110, 1-12.

Frank, J.H. \& Morón, M.A. (2012) Natural history of four species of Platydracus Thomson (Coleoptera: Staphylinidae) in Heliconia bourgaeana Petersen (Zingiberales: Heliconiaceae) flower bracts. Insecta Mundi, 258, 1-12.

Guimarães, J.A. \& Mendes, J. (1998) Succession and abundance of Staphylinidae in cattle dung in Uberlândia, Brazil. Memórias do Instituto Oswaldo Cruz, 93, 127-131. http://dx.doi.org/10.1590/S0074-02761998000100024

Goff, M.L. (1993) Estimation of postmortem interval using arthropod development and successional patterns. Forensic Science Review, 5 (2), 81-94.

Grebennikov, V.V. \& Newton, A.F. (2009) Good-bye Scydmaenidae: or why the ant-like stone beetles should become megadiverse Staphylinidae sensu latissimo (Coleoptera). European Journal of Entomology, 106, 275-301. http://dx.doi.org/10.14411/eje.2009.035

Gutiérrez-Chacón, C. \& Ulloa-Chacón, P. (2006) Composición de estafilínidos (Coleoptera: Staphylinidae) asociados a hojarasca en la cordillera Oriental de Colombia. Folia Entomológica Mexicana, 45, 69-81

Hadley, A. (2014) CombineZP. Available from: http://www.hadleyweb.pwp.blueyonder.co.uk/CZP/News.htm (Accessed 20 April 2014)

Herman, L.H. (2001) Catalog of the Staphylinidae (Insecta: Coleoptera). 1758 to the end of the second millennium. Part V. Bulletin of the American Museum of Natural History, 265, 2441-3020.

Hu, G.Y. \& Frank, J.H. (1997) Predation on the horn fly (Diptera: Muscidae) by five species of Philonthus (Coleoptera: 
Staphylinidae). Environmental Entomology, 26, 1240-1246.

Irmler, U. (1982) A new species of the Neotropical genus Xenopygus Bernhauer (Coleoptera: Staphylinidae). Coleopterists Bulletin, 36, 206-210.

Klimaszewski, J. (1984) A revision of the genus Aleochara Gravenhorst in America north of Mexico (Coleoptera: Staphylinidae, Aleocharinae). Memoirs of the Entomological Society of Canada, 129, 1-211. http://dx.doi.org/10.4039/entm116129fv

Klimaszewski, J. \& Jansen, R.E. (1993) Systematics, biology and distribution of Aleochara Gravenhorst from Southern Africa. Part I: subgenus Xenochara Mulsant \& Rey (Coleoptera: Staphylinidae). Annals of the Transvaal Museum, 36, 53-107.

Kulshrestha, P. \& Satpathy, D.K. (2001) Use of beetles in forensic Entomology. Forensic Science International, 120, 15-17. http://dx.doi.org/10.1016/S0379-0738(01)00410-8

Lüderwaldt, G. (1911). Os insetos necrófagos paulistas, Revista do Museu Paulista, 8, 414-433.

Lin, S.W. \& Shiao, S.F. (2013) Life history data on the fly parasitoids Aleochara nigra Kraatz and A. asiatica Kraatz (Coleoptera: Staphylinidae), and their potential application in forensic entomology. Forensic Science International, 232 , 46-55 http://dx.doi.org/10.1016/j.forsciint.2013.06.016

Lynch-Arribálzaga, F. (1884) Estafilinos de Buenos Aires. Boletín de la Academia Nacional de Ciencias, Córdoba, 7, 5-256.

Mariani, R., Garcia-Mancuso, R., Varela, G.L. \& Inda, A.M. (2014) Entomofauna of a buried body: Study of the exhumation of a human cadaver in Buenos Aires, Argentina. Forensic Science International, 237, 19-26. http://dx.doi.org/10.1016/j.forsciint.2013.12.029

Mariani, R., Varela, G.L., Demaría, M. \& Rossi-Batiz, M.F. (2010) Registro de la artropodofauna cadavérica asociada a restos humanos en situaciones forenses en la provincia de Buenos Aires, República Argentina. Libro de Resumenes XI Congreso Nacional de Criminalística; VII Congreso Internacional de Criminalística y Ciencias Forenses; IX Congreso Iberoamenicano de Criminalística y Ciencias Forenses. Misiones (Argentina), September 2010, 1-7.

Martínez, E., Duque, P. \& Wolff, M. (2007) Succession pattern of carrion-feeding insects in Páramo, Colombia. Forensic Science International, 166, 182-189. http://dx.doi.org/10.1016/j.forsciint.2006.05.027

Márquez-Luna, J. (2001) Especies necrofilas de Staphylinidae (Insecta: Coleoptera) del municipio de Tlayacapan, Morelos, Mexico. Folia Entomologica Mexicana, 40, 93-131.

Márquez, J. \& Asiain, J. (2002) Eulissus chalybaeus Mannerheim, 1830, Coleoptera: Staphylinidae, Xantholinini. Dugesiana, 9 (2), 67-68.

Matuszewski, S. (2012) Estimating the pre-appearance interval from temperature inCreophilus maxillosus L. (Coleoptera: Staphylinidae). Journal of Forensic Sciences, 57, 136-145. http://dx.doi.org/10.1111/j.1556-4029.2011.01958.x

Matuszewski, S., Bajerlein, D., Konwerski, S. \& Szpila, K. (2008) An initial study of insect succession and carrion decomposition in various forest habitats of Central Europe. Forensic Science International, 180, 61-9. http://dx.doi.org/10.1016/j.forsciint.2008.06.015

Matuszewski, S., Bajerlein, D., Konwerski, S. \& Szpila, K. (2010) Insect succession and carrion decomposition in selected forests of Central Europe. Part 2: Composition and residency patterns of carrion fauna. Forensic Science International, 195, 42-51. http://dx.doi.org/10.1016/j.forsciint.2009.11.007

Matuszewski, S. \& Szafałowicz, M. (2013). Temperature-dependent appearance of forensically useful beetles on carcasses. Forensic Science International, 229, 92-99. http://dx.doi.org/10.1016/j.forsciint.2013.03.034

Maus, C. (2001) Redescription of Aleochara (Coprochara) signaticollis Fairmaire \& Germain, 1861, an overlooked species. 3rd taxonomic contribution to the subgenus Coprochara Mulsant \& Rey, 1874 of the genus Aleochara Gravenhorst, 1802 (Coleoptera: Staphylinidae). Koleopterologische Rundschau, 71, 37-48.

Maus, C., Mittman, B. \& Peschke, K. (1998) Host records of parasitoid Aleochara Gravenhorst species (Coleoptera: Staphylinidae) attacking puparia of cyclorrhaphous Diptera. Deutsche Entomologische Zeitschrift, 45, 231-254.

Midgley, J.M., Richards, C.S. \& Villet, M.H. (2010) The utility of Coleoptera in forensic investigations. In: Amendt, J., Goff, M.L. \& Campobasso, C.P., Grassberger, M, (Eds.), Current concepts in forensic entomology. Springer, Dordrecht, Netherlands, pp. 57-68.

Mise, K.M., Massutti, L. \& Moura, M.O. (2007) Levantamento da fauna de Coleoptera que habita a carcaça de Sus scrofa L., em Curitiba, Paraná. Revista Brasileira de Entomologia, 51 (3), 358-368. http://dx.doi.org/10.1590/S0085-56262007000300014

Morales, C.J. \& Aguilar-Astudillo, E. (2012) Primer registro de Oligotergus mexicanus (Sharp, 1884) (Coleoptera: Staphylinidae: Staphylininae) para Chiapas, México. Dugesiana, 19 (1), 42.

Navarrete-Heredia, J.L., Newton, A.F., Thayer, M.K., Ashe, J.S. \& Chandler, D.S. (2002) Guía ilustrada para los géneros de Staphylinidae (Coleoptera) de México. Illustrated guide to the genera of Staphylinidae (Coleoptera) of México. Universidad de Guadalajara y Conabio, México. $401 \mathrm{pp}$.

Newton, A.F., Thayer, M.K., Ashe, J.S. \& Chandler, D.S. (2000) Staphylinidae Latreille, 1802. In: Arnett, R.H. \& Thomas, M.C. (Eds.), American Beetles. Vol.1. Archostemata, Myxophaga, Adephaga, Polyphaga: Staphyliniformia. CRC Press, 
Boca Raton, pp. 272-418.

Newton, A.F. \& Thayer, M.K. (2005) Catalog of higher taxa of Staphyliniformia and genera and subgenera of Staphylinoidea [online]. Field Museum of Natural History, Chicago. Available from: http://www.fieldmuseum.org/peet_staph/db_1a.html (accessed 3 May 2013)

Noriega, J.A. \& Navarrete-Heredia, J.L. (2013) Quantification of predation on the dung beetle Canthidium cupreum (Blanchard) (Coleoptera: Scarabaeidae: Scarabaeinae) by Leistotrophus versicolor (Gravenhorst) (Coleoptera: Staphylinidae). The Coleopterists Bulletin, 67 (2), 190-193. http://dx.doi.org/10.1649/0010-065X-67.2.190

Olson, D.M., Dinerstein, E., Wikramanayake, E.D., Burgess, N.D., Powell, G.V.N., Underwood, E.C., D'Amico, J.A., Itoua, I., Strand, H.E., Morrison, J.C., Loucks, C.J., Allnutt, T.F., Ricketts, T.H., Kura, Y., Lamoreux, J.F., Wettengel, W.W., Hedao, P. \& Kassem, K.R. (2001) Terrestrial Ecoregions of the World: A New Map of Life on Earth. BioScience, 51 (11), 933-938.

Özdemir, S. \& Sert, O. (2009) Determination of Coleoptera fauna on carcasses in Ankara province, Turkey. Forensic Science International, 183, 24-32. http://dx.doi.org/10.1016/j.forsciint.2008.09.018

Peschke, K. \& Fuldner, D. (1977) Ubersicht und neue Untersuchungen zur Lebensweise der parasitoiden Aleocharinae (Coleoptera: Staphylinidae). Zoologische Jahrbucher: Abteilung fur Systematik, Okologie und Geographie der Tiere, 104, 242-262.

Prado e Castro, C., García, M.D. Martins da Silva, P. Faria e Silva, I. \& Serrano, A. (2013) Coleoptera of forensic interest: A study of seasonal community composition and succession in Lisbon, Portugal. Forensic Science International, 232, 73-83. http://dx.doi.org/10.1016/j.forsciint.2013.06.014

Smetana, A. (1995) Rove beetles of the subtribe Philonthina of America north of Mexico (Coleoptera: Staphylinidae): Classification, phylogeny and taxonomic revision. Memoirs on Entomology, International, 3, 1-946.

Smith, K.G.V. (1986) A manual of forensic entomology. Ithaca, NY, Cornell University Press, 205 pp.

Segura, N.A., Usaquén, W. \& Sánchez, M.C. (2009) Succession pattern of cadaverous entomofauna in a semi-rural area of Bogotá, Colombia. Forensic Science International, 187, 66-72. http://dx.doi.org/10.1016/j.forsciint.2009.02.018

Thayer, M.K. (2005) 11. Staphylinoidea. 11.7. Staphylinidae Latreille, 1802. In: Beutel, R.G. \& Leschen, R.A.B., (Eds.), Coleoptera, Vol. 1. Morphology and Systematics (Archostemata, Adephaga, Myxophaga, Polyphaga partim), Handbook of Zoology, Vol. IV, Arthropoda: Insecta, Part 38, Kristensen, N.P. \& Beutel, R.G., (Eds.), De Gruyter, Berlin, New York, pp. 296-344.

Turchetto, M., Lafisca, S. \& Constantini, G. (2001) Post mortem interval (PMI) determined by study of sarcophagous biocenoses: three cases from the province of Venice (Italy). Forensic Science International, 120, 28-31. http://dx.doi.org/10.1016/S0379-0738(01)00412-1

Turchetto, M. \& Vanin, S. (2004) Forensic entomology and climatic change. Forensic Science International, 146, $207-209$. http://dx.doi.org/10.1016/j.forsciint.2004.09.064

VanLaerhoven, S.L. \& Anderson, G. (1999) Insect succession on buried carrion in two biogeoclimatic zones of British Columbia, Journal of Forensic Sciences, 44, 32-43.

Villet, M.H. (2011) African carrion ecosystems and their insect communities in relation to forensic entomology: a review. Pest Technology, 5 (1), 1-15.

Wolff, M., Uribe, A., Ortiz, A. \& Duque, P. (2001) A preliminary study of forensic entomology in Medellín, Colombia. Forensic Science International, 120, 53-59. http://dx.doi.org/10.1016/S0379-0738(01)00422-4

Young, O.P. (2011) Staphylinid predation on large dung neetles (Coleoptera: Staphylinidae, Scarabaeidae) in Panama. The Coleopterists Bulletin, 65 (3), 227-229.

http://dx.doi.org/10.1649/072.065.0303 